\title{
Japanese cedar (Cryptomeria japonica D.Don, Taxodiaceae) flowers in Arun Kumar Sharma Botanic Garden (AKSBG) at Kolkata, West Bengal, India
}

\author{
Debabrata Maity ${ }^{1}$ and Sourav Moktan \\ Department of Botany, University of Calcutta \\ 35, Ballygunge Circular Road, Kolkata - 700 019, West Bengal, India \\ ${ }^{1}$ Communicating author; E-mail: debmaity@yahoo.com
}

[Received 02.12.2019; Revised \& accepted 27.12.2019; Published 31.12.2019]

\begin{abstract}
Arun Kumar Sharma Botanic Garden (AKSBG), the Department of Botany, University of Calcutta is an important germplasm collection center in India. The paper discussed the introduction and flowering of Cryptomeria japonica D. Don in this garden.
\end{abstract}

Key words: Cryptomeria japonica, exotic, plantation, phenology.

Cryptomeria D. Don is a monotypic genus of the ancient conifer family Taxodiaceae. The sole member of the genus $C$. japonica D. Don, commonly known as Japanese cedar, is a tall, handsome evergreen tree with a conical crown on an erect tall trunk, attaining a height of even $75 \mathrm{~m}$. This species is a native to Japan and China, though successfully introduced in different parts of the world including India. The Darjeeling and Sikkim Himalaya are with huge old and dense plantations of the species. The robust, straight trunk supports the branches and drooping branchlets. The leaves are spirally arranged, awl-shaped, with sharp pointed apices and bluish green. The brownish bark, sometimes possess transverse fine wrinkled bands, that peels off into vertical stripes. The socio-economic impact of this species is remarkable. In Eastern Himalayan region, particularly in Darjeeling and Sikkim areas $C$. japonica is planted as holy tree, as its foliage is used by the local inhabitants as an easy source of incense. Apart from this, other significant uses of the plant are as ornamental avenue tree, source of lumber as well as a wind break (Hosoo 2007). Importantly, the wood of the plant has a pleasant odour and colour possibly due to high resin content and is weather, insect and rot resistant. Timber is mostly used for different type of construction works including houses, bridges and furniture as well as for making utensils (Ohba 1993; Fu et al. 1999; Hosoo 2007).

Due to its dense and continuous canopy of high plantations, the inside of such manmade forests remain dark. At the same time, litters on the forest floor takes exceptionally long time to decompose that lead to the accumulation of thick immature humus which is extremely acidic and warm inside. All these conditions are highly unsuitable for the growth and survival of most of the local plants and animals (Das 1995; Das \& Lahiri 1997). So, the environmentalists demand the discontinuation of this economically much useful but ecologically disastrous foreign element.

Arun Kumar Sharma Botanic Garden (AKSBG), at the Department of Botany, University of Calcutta, one of the oldest botanic gardens of the country was established in 1918 in Taraknath Palit Siksha Prangan (Ballygunge Science College Campus). The garden is a repository of many important plants and is also a significant conservation site for many 

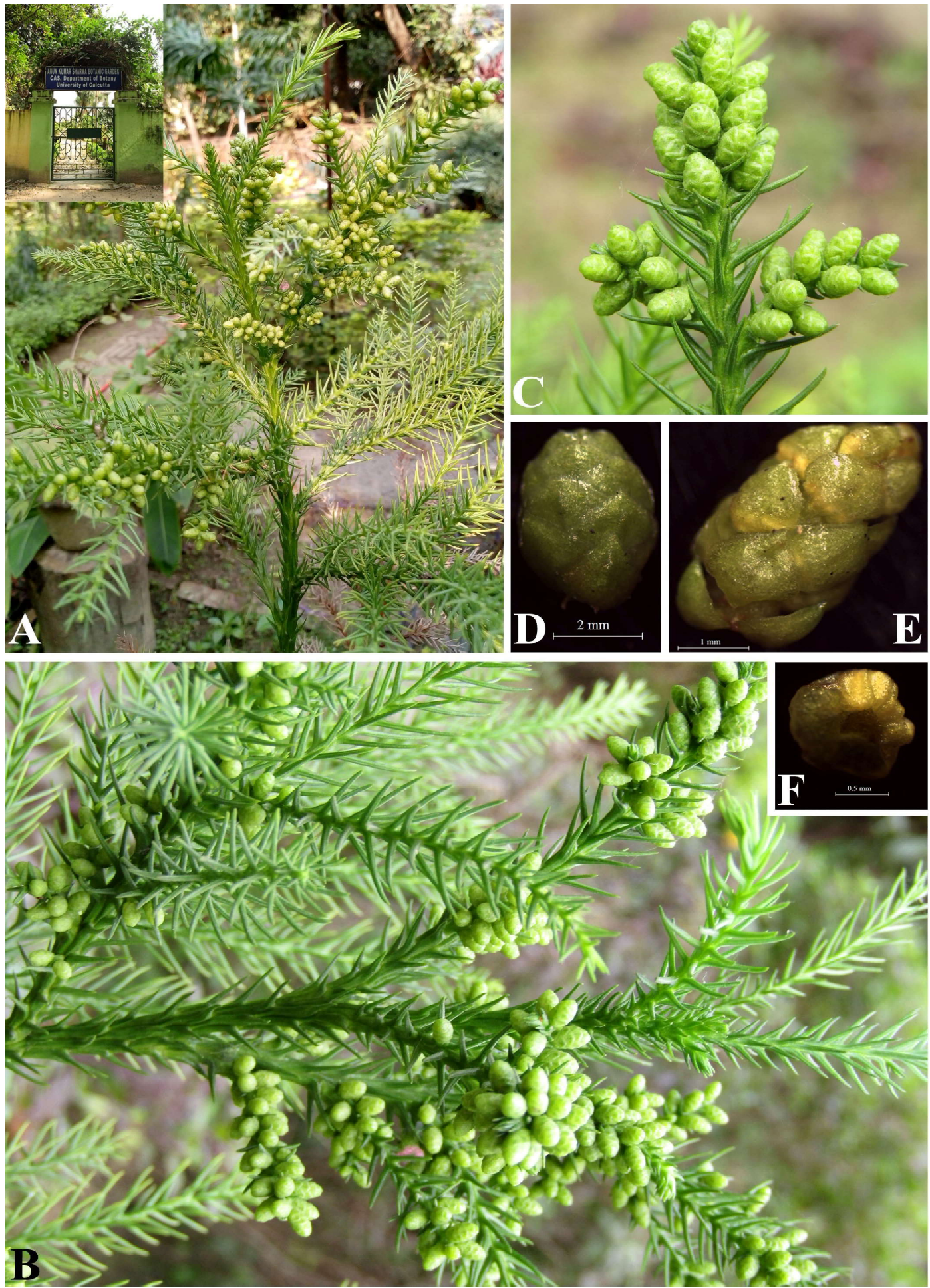

PLATE - I. Cryptomeria japonica: A. Plant at AKSBG (inset: AKSBG entrance); B\&C. Branchlets with male strobili; D. Immature strobilus; E. Mature strobilus; F. Microsporophyll 
rare species including some RET mangroves (Maity 2015). Notably, the collection of gymnosperms is remarkable. In recent years few plants including Ephedra foliata, Pinus wallichiana, Podocarpus neriifolia, etc. are introduced successfully. In 2017 one sapling of Cryptomeria japonica of about two years old was planted in the AKSBG premises with proper care. The plant was introduced from Mirik area of Darjeeling district. As this is a cold loving plant, grows in subtropical to temperate climate, proper management was done in garden condition. The high temperature and humidity rainfall were the main concern against its survival. In Darjeeling Hills, the plant is growing with temperature and rainfall varies between $4^{\circ} \mathrm{C}-25^{\circ} \mathrm{C}$ and $500-600 \mathrm{~cm} /$ per annum, respectively. However, in Kolkata temperature commonly varies between $14^{\circ} \mathrm{C}$ to $40^{\circ} \mathrm{C}$, sometimes even more and an annual rainfall of around $170 \mathrm{~cm}$. The main challenge was to provide maximum favorable conditions to the plant at the garden through sufficient and controlled irrigation and protection from direct sunlight in summer. For this purpose direct irrigation to the plant was done supplemented by mist using suitable sprinkler. After a considerable effort the plant survives and is in good health. Presently, the plant is about $1 \mathrm{~m}$ in height. The most significant fact is that the plant is in full bloom this year (2019). The small plant is with numerous matured male strobili. Though C. japonica is a monoecious tree, however, no female cone is developed till date at AKSBG (PLATE - I).

The development and biology of male and female strobili in C. japonica has been studied by several workers all over the world (Takaso \& Tomlinson 1989; Shi 2008; Tsubomura et al. 2016). In nature, the primordia of male strobili are initiated from late June to late September and since flower bud initiation, the primordia grew rapidly and started to form sporogenous tissue, and the formation of pollen grains was observed from the middle of September to early November. Usually, reproduction in conifers begins5-10 years after planting and most conifers rarely bear male strobili or female cones in their juvenile period without artificial treatment to stimulate their reproductive (Williams 2009; Tsubomura et al. 2016). The plant at AKSBG, however, starts flowering at late May and the formation of pollen grains is observed from mid-August to December. The difference in the time of initiation of male strobili and respective pollen formation is possibly due to change in climatic conditions. The male strobili are small ellipsoid to ovoid and arise in the axils of leaves (bracts). At the end of June initiation of sporangia has been noticed and were photographed. After about two months, sporangia become mature and produced mature pollen grains. In the male strobilus bracts are spirally arranged and lower most $2-3$ microsporophylls are sterile, devoid of any sporangium structure. Upper all microsporophylls are fertile and bear four sporangia at base on abaxial side. Mature sporangia are yellowish, full of pollen grains. The pollen of $C$. japonica is allergic and causes pollinosis. In Japan, this is a major source of aeroallergens in early spring and causes rhinitis and conjunctivitis (Hosoo 2007).

Another significant change that has been observed in the plant at AKSBG is the position of male stobili. In nature, the male stobili were formed in the axils of the apical portion of the current year's shoots, whereas the female cone grows from the terminal bud on the current year's shoot. However, in the plant at AKSBG male strobili are formed from the base to near apex of branchlets, though basal strobili are comparatively healthier, however, in several cases all strobili of the branchlets are in good shape and healthy. Some scattered strobili are also seen along the branches.

Male reproductive organs in $C$. japonica have already been studied by several workers (Futamura et al. 2008; Tsubomura et al. 2012; Kurita et al. 2013). However, formation of male strobili in $C$. japonica at Kolkata, in such a warm tropical climate where temperature reaches over $40^{\circ} \mathrm{C}$ in summer, is of great concern as well as of scientific value. Research on 
the differences of the events associated with this fact as discussed and pointed out above that will through light on the reproductive biology of the species. Moreover, this information would be useful for breeding, genetic research and other branches of science dealing with this important species.

\section{Acknowledgements}

Authors are thankful to the Head, Department of Botany, University of Calcutta for providing facilities. All faculty members as well as staff of the Department of Botany, University of Calcutta are warmly thanked for their inspiration and help. We thank Mr. Sudip Das, Gardener, AKSBG for his whole hearted support. They are also thankful to the University of Calcutta for financial assistance. Help received from Dr. Subrata Karmakar, Asstt. Secretary, C.U., Mr. Dhoni and his team, Mr. Ramayan Yadav, Mr. Jayanata Ghosh, Mr. Mrinmoy Midday and all students of the department is gratefully acknowledged.

\section{LITERATURE CITED}

Das, A.P. \& Lahiri, A.K. 1997. Phytosociological studies of the ground covering flora in different types of vegetation in Tiger Hill, Darjeeling District, West Bengal (India). Indian For. 123(12): 1176 - 1187.

Das, A.P. 1995. Diversity of the angiospermic flora of Darjeeling Hills. In: Pandey, A.K. (ed.), Taxonomy and Biodiversity. CBS, New Delhi. pp. 118 - 127.

Fu, L.; Yu, Y. \& Mill, R.R. 1999. Taxodiaceae. In: Wu, Z. and Raven, P.H. (eds.), Flora of China. Vol. IV. Science Press, Beijing. Pp. $11-61$.

Futamura, N.; Totoki, Y. \& Toyoda, A. 2008. Characterization of expressed sequence tags from a full-length enriched cDNA library of Cryptomeria japonica male strobili. BMC Genomics 9: 383.

Hosoo, Y. 2007. Development of pollen and female gametophytes in Cryptomeria japonica. Intn. J. Pl. Dev. Bio. 1(1): 116 - 121.

Kurita, M.; Konagaya, K.; Watanabe, A.; Kondo, T.; Ishii, K. \& Taniguchi, T. 2013. The promoter of an $A 9$ homolog from the conifer Cryptomeria japonica imparts male strobilus-dominant expression in transgenic trees. Plant Cell Rep. 32: 319-328.

Maity, D. 2015. Calcutta University Herbarium and Experimental Garden. In: History of Botany - in the most premier university in India. University of Calcutta. Pp. $359-373$.

Ohba, K. 1993. Clonal forestry with sugi (Cryptomeria japonica). In: Ahuja, M.R. \& Libby, W.J. (eds.), Clonal forestry II, Conservation and application. Springer-Verlag, Berlin. Pp. $66-90$.

Shi, N.R. 2008. Initiation and development of flower buds in Cryptomeria japonica. J. Japan. For. Soc. DOI: 10.11519/jjfs 1953.44.11_312.

Takaso, T. \& Tomlinson, P. B. 1989. Aspects of Cone and Ovule Ontogeny in Cryptomeria (Taxodiaceae). American J. Bot. 76(5): $692-705$.

Tsubomura, M.; Fukatsu, E.; Nakada, R. \& Fukuda, Y. 2012. Inheritance of male flower production in Cryptomeria japonica (sugi) estimated from analysis of a diallel mating test. Ann. For. Sci. 69: $867-875$.

Tsubomura, M.; Kurita, M. \& Watanabe, A. 2016. Determination of male strobilus developmental stages by cytological and gene expression analyses in Japanese cedar (Cryptomeria japonica). Tree Physiol. 36: 653 - 666.

Williams, C.G. 2009. Conifer reproductive biology. Springer, New York. 